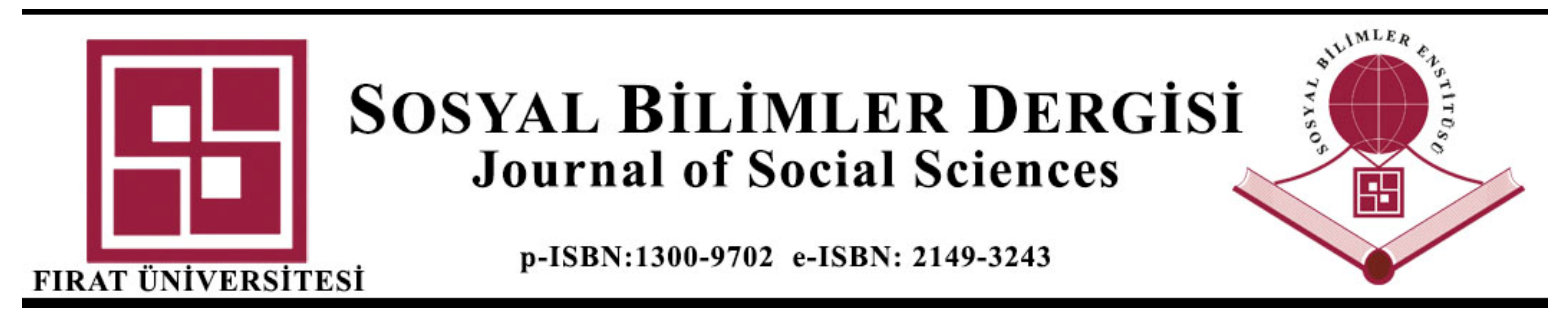

\title{
REVIEW OF CITY PARKS IN TERMS OF DISABLED RIGHTS
}

\author{
Engelli Hakları Açısından Şehir Parklarının İncelenmesi \\ Nilüfer CETIŞLİ-KORKMAZ ${ }^{1}$, Furkan BİLEK ${ }^{2}$, Esra DOĞRU-HUZMELİ ${ }^{3}$, Özden GÖKÇEK ${ }^{4}$ \\ ${ }^{1}$ Prof. Dr., Pamukkale University School of Physiotherapy and Rehabilitation, 20160, Denizli, Turkey, \\ niluferc75@yahoo.com,orcid.org/0000-0003-3471-8240

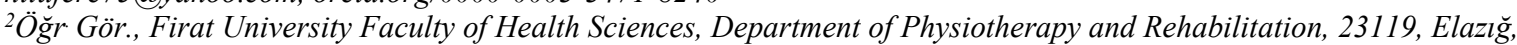 \\ Turkey,fzt.furkanbilek@gmail.com,orcid.org/0000-0003-1567-7201 \\ ${ }^{3}$ Doç. Dr., Hatay Mustafa Kemal University Faculty of Health Sciences, Department of Physiotherapy and \\ Rehabilitation, 31060, Hatay, Turkey, esradogru001@hotmail.com,orcid.org/0000-0002-7025-8192 \\ ${ }^{4} \ddot{O} \breve{g r}$ Gör., Hatay Mustafa Kemal University Faculty of Health Sciences, Department of Physiotherapy and \\ Rehabilitation, 31060, Hatay, Turkey, ozdengokcek44@gmail.com, orcid.org/0000 000333964108
}

Araştırma Makalesi/Research Article

Makale Bilgisi

Geliş/Received:

25.03.2021

Kabul/Accepted:

26.07.2021

DOI:

10.18069/firatsbed.902896

Keywords

Disability, park use, social participation, health.

\begin{abstract}
The creation and presentation of independent and individual spaces for disabled individuals is the most important step of social integration. The main purpose of this report is to investigate whether some city parks in Turkey are suitable or not for the use of disabled individuals. This descriptive research includes the perception of disabled individuals about the city parks in Hatay, Şanlıurfa and Gaziantep provinces. Individuals with disabilities assessed the structure of city parks, ease of use, ergonomics and basic needs with basic 22questions. The questions focused on respondents' experiences with specific destinations and environmental barriers. 150 disabled individuals, 53 from Hatay, 53 from Şanlıurfa and 44 from Gaziantep, were included in the study. Participants; $29.3 \%$ were using wheelchairs, $34 \%$ were using electric wheelchairs, $30 \%$ were using crutches and $6.7 \%$ were not using assistive devices. As a result of the study, it was seen that the parks were not convenient and useful for the disabled individuals. Deficiencies in city parks can avoid evaluating and ensuring the leisure time activities, social compliance and exercise activities for disabled individuals. Thus, we think that these environments can maximize opportunities for leisure activities and social participation by individuals with lifelong disabilities.
\end{abstract} Engellilik, park kullanımı, sosyal katılım, sağlık.
Anahtar Kelimeler

\begin{abstract}
ÖZ
Engelliler için bağımsız ve bireysel alanların oluşturulması ve sunulması, sosyal entegrasyonun en önemli adımıdır. Bu çalışmanın temel amacı, Türkiye'deki bazı şehir parklarının engelli bireylerin kullanımına uygun olup olmadığını araştırmaktır. Bu tanımlayıcı araştırma, engelli bireylerin Hatay, Şanlıurfa ve Gaziantep illerindeki şehir parklarına yönelik algılarını içermektedir. Engelli bireyler, kent parklarının yapısını, kullanım kolaylığını, ergonomisini ve temel ihtiyaçlara ulaşılabilirliğini 22 temel soruyla değerlendirdiler. Sorular, yanıtlayanların belirli destinasyonlar ve çevresel engellerle ilgili deneyimlerine odaklanmıştır. Çalışmaya Hatay'dan 53, Şanlıurfalı 53 ve Gaziantep'ten 44 kişi olmak üzere 150 engelli birey dâhil edildi. Katılımcılar; \% 29,3'ü tekerlekli sandalye, \% 34'ü akülü tekerlekli sandalye, \% 30'u koltuk değneği kullanırken, \% 6,7'si yardımcı cihaz kullanmıyordu. Araştırma sonucunda parkların engelli bireyler için uygun ve kullanışlı olmadığı görüldü. Kent parklarındaki eksiklikler, engelli bireyler için boş zaman aktiviteleri, sosyal uygunluk ve egzersiz faaliyetlerinin değerlendirilmesini ve sağlanmasını engelleyebilir. Bu nedenle, bu ortamların engelli bireylerin kullanıma uygun olması yaşam boyu engelli bireylerin boş zaman etkinlikleri ve sosyal katılım firsatlarını en üst düzeye çıkarabileceğini düşünüyoruz.
\end{abstract}

Atıf/Citation: CETIŞLİ-KORKMAZ1, N., BİLEK, F., DOĞRU-HUZMELİ, E., GÖKCEK, Ö., (2021). Review of City Parks in Terms of Disabled Rights, Firat Üniversitesi Sosyal Bilimler Dergisi, 31, 3(1299-1309).

Sorumlu yazar/Corresponding autohor: Furkan BİLEK, fzt.furkanbilek@gmail.com 


\section{Introduction}

For the adaptation of disabled people to social life, it is important that urban structures are designed appropriately. City parks, especially where people perform their social activities, are crucial in this regard. So much so that these social rights of disabled individuals are also protected by laws. The United Nations General Assembly adopted the "United Nations Standards Rules for Providing Equal Opportunities for the Disabled" on 20 December 1993 with its decision numbered 48/96. In the 27th session of the European Continuous Meeting of Local and Regional Authorities working under the European Union, held in Strasbourg on 17 - 19 March 1992, the "European Urban Charter" was adopted. It was stated that this condition should be designed according to the principle of integrating the disabled people in the cities with the society (Özdingiş 2007). In Turkey, with the start of the harmonization process after the EU membership application, some laws and regulations have been enacted on the accessibility of cities. In this context, the most important law enacted to ensure unimpeded access in cities in Turkey is the Law on Disabled People, numbered 5378, dated 01.07.2005. However, according to Law No. 5387, accessibility is defined as "the safe and independent access and use of buildings, open spaces, transportation and information services, and information and communication technology by the disabled" (Uçar and Şemşit, 2019: 18). In line with this information, we aimed to evaluate the structure of city parks, which are also regulated by law, according to the assistive devices used by disabled individuals.

After the Industrial Revolution, the cities became the living areas where the crowded population has accumulated due to the rapid and intensive migration of the cities. The rapid growth of its population led to the formation of unhealthy and unplanned urbanization. Today, the errors in the design of cities cause loss of productivity on unimpeded individuals, meanwhile the problems of individuals carrying temporary or permanent obstacles increased gradually (Uçar, Şemşit, and Negiz 2017). The World Health Organization (WHO) defines the individuals' disabilities by covering both environmental and physical factors (Barbotte, Guillemin and Chau 2011).

As in the rest of the world, disabled individual constitutes a significant part of the population in Turkey. According to the latest data, there are about 9 million disabled individuals in Turkey. In other words, one out of every 9 people has a disability. Our highly disabled population, of course, must have equal rights like other individuals. For this purpose, social integration and participation begins with the integration of the individual to the city and the life functions of the city. The creation and presentation of independent and individual spaces for disabled individuals is the most important step of social integration. The most important characteristic of being a contemporary society is providing opportunities for all people to live humanely without any difference. Nevertheless, obstruction detection features are the problems that prevent social integration of disabled individuals, who are integral parts of society. One of the biggest obstacles in the social life of disabled individual is the physical environment that is not designed for disabled individuals (Bekci 2012; Smith, Sakakibara, and Miller 2016; Harris, Yang, and Sanford 2015).

In today's modern societies, city parks are places where individuals can meet their physical and psychological needs and reduce social isolation. Thus, designing the city parks properly is the most important solution to the problems faced in socialization of disabled individuals (Sanmargaraja and Wee 2015). If the disabled individual can use a space without restriction and conveniently alone, the individual will no longer be regarded as disabled (Bulgan and Göktaş 2016). For this reason, it is primarily necessary for disabled individual to access city parks and to organize them as unhindered parks (Bromley, Matthews, and Thomas 2007; Smith, Sakakibara, and Miller 2016; Harris, Yang, and Sanford 2015). People with greater access to recreation facilities engage in more physical activity. Although access to physical activity facilities and programs is associated with activity levels of youth and adults, inequalities in access to physical activity resources have not been widely studied, and results are not consistent (Abercrombie LC). The aim of this study is to investigate whether city parks in Turkey are suitable for the use of disabled individuals or not.

\section{Materials and Methods}

Disabled individuals from Hatay $(n=53)$, Şanlıurfa $(n=53)$ and Gaziantep $(n=44)$ included to this research with descriptive design. All participants gave written informed consent before participation, and the study 
protocol conformed to the standards for human experiments set by the Declaration of Helsinki and was approved by the Local Ethics Committee (42598783-050-12-7855).

\subsection{Procedure}

Individuals with disabilities who agreed to participate to the study were asked to complete the questionnaire, which took $15 \mathrm{~min}$. The first part of the questionnaire consists of questions regarding participants' demographic characteristics (e.g. sex, age, marital status, having children, education level, and occupation), type of disability and disability status. In the second part, the experiences of participants regarding usage, specific destinations and environmental barriers of city parks were questioned with 22 questions. The questionnaire's 22 questions compiled from the studies conducted in Turkey (Özdingiş 2007; Eşkil 2011; Yılmaz et al. 2012).

\subsection{Statistical Analysis}

Statistical analysis done with SPSS (Statistical Package for the Social Sciences) for Windows 20.0 (IBM Corp.). The mean \pm standard deviation $(\mathrm{X} \pm \mathrm{SD})$, number $(\mathrm{n})$ and percentile (\%) used for the descriptive analysis. The significant differences in categorical variables analyzed using Chi-Square Test. Sociodemographic and individual characteristics of participants were calculated as numbers and percentages. The mean and standard deviation of variables were calculated. Correlations between auxiliary device used and the structure of city parks (ease of use, ergonomics and basic needs with basic 22-questions) analyzed through Spearman Correlation Test.

\section{Results}

This cross-sectional study's sample group consisted of 150 individuals with disability. Approximately $29.3 \%$ of them were using manual wheelchair, $34 \%$ were using wheelchair with battery, $30 \%$ were using crutches and $6.7 \%$ were not using an assistive device. All participants were grouped according to the assistive device that they used for their mobility; as manual wheelchair users, wheelchair with battery users, crutch users and participant who do not use a device. Disability levels in the official disability reports of the participants were $63.07 \pm 5.97 \%, 76.45 \pm 12.74 \%, 52.24 \pm 6.86 \%$ and $48.00 \pm 3.77 \%$, respectively $(\chi 2=93.083, p=0.000)$. The highest disability ratio was in wheelchair users with battery, while the lowest disability ratio was in the group who do not use an assistive device. There was also a statistically significant difference between the types of disability. Individuals with orthopedic disability are more likely to use assistive devices than the individuals with neurologic disability, $90 \%$ of individuals with neurological type disability do not use assistive $(p<0.05$, Table 1).

Table 1. City and disability type of participants.

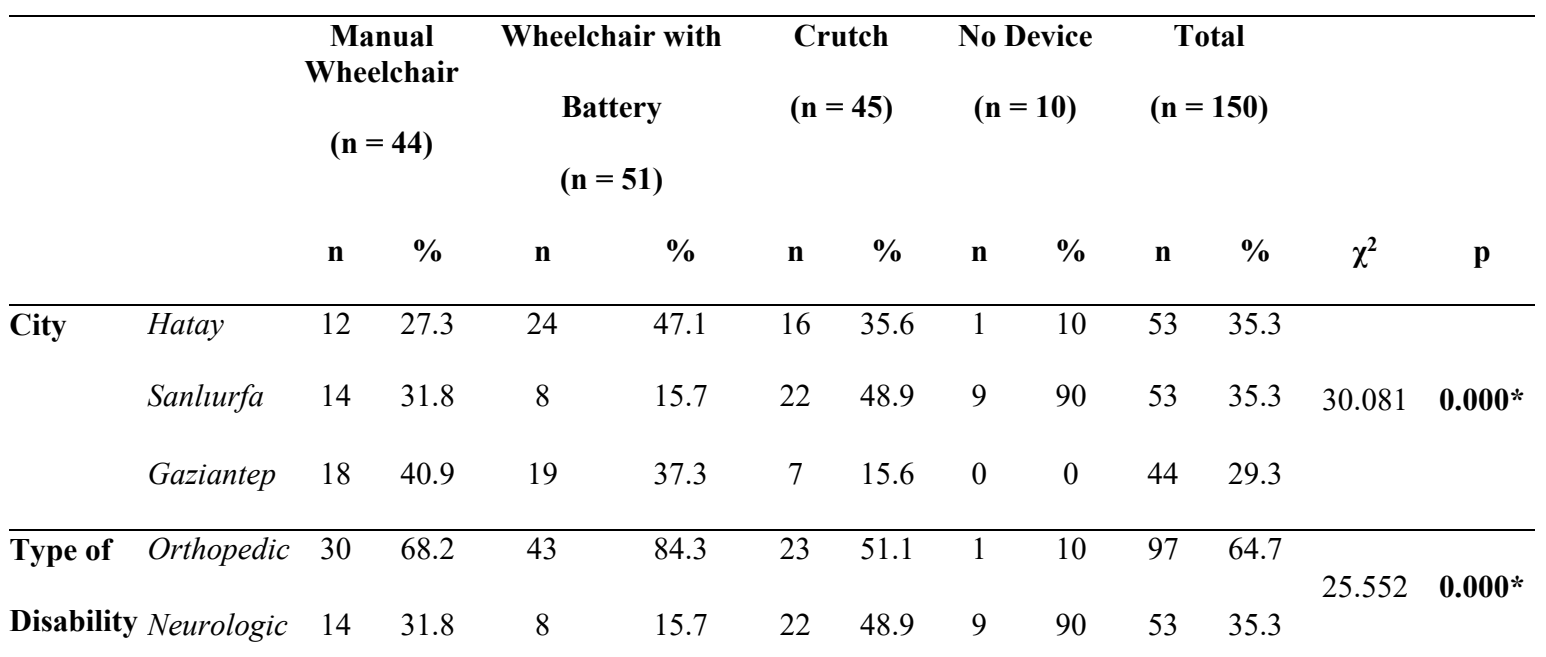


The most $(87.3 \%)$ of the individuals" answers were "No" to the question of "Do you hesitate to use the park in the suitable weather conditions?", while $94.7 \%$ of them answered as "Yes" to the question of "Do you hesitate to use the park in the bad weather conditions?". According to device usage, when we evaluate groups within themselves, it was determined that more individuals who did not use an assistive device hesitate to use city parks both in suitable weather conditions (40\%) and in unfavorable weather conditions (100\%) (Table 2 ). These results showed that using an assistive device and favorable weather conditions would be much convenient and easy for them to use the park.

Table 2. Access and usage of the city parks

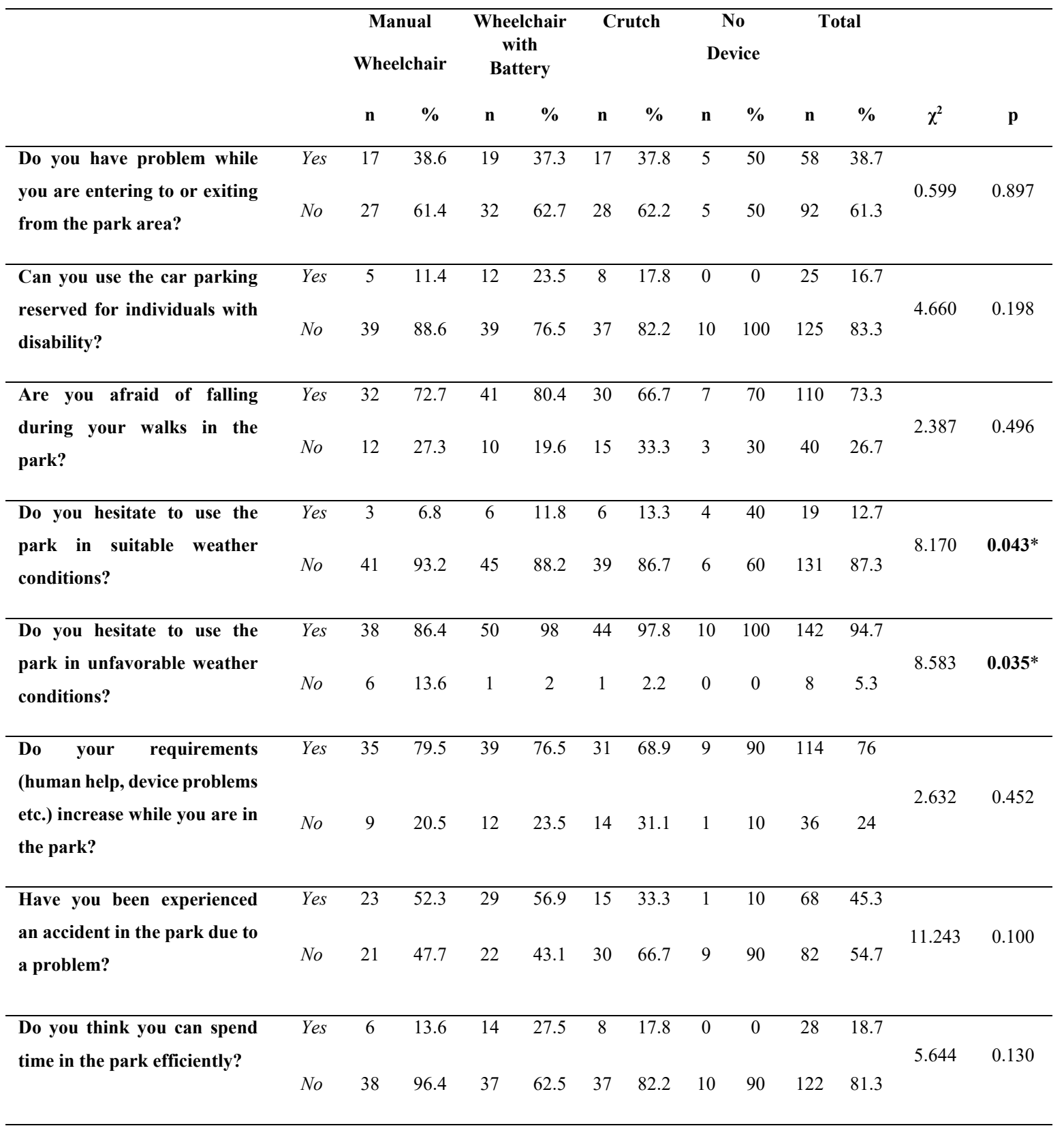


For the "Does the park's ground make your movement harder?", "Are you afraid of falling during your walks in the park?", "Could you access to the drinking-water area in the park?", and "Do you requirements (human help, device problems etc.) increase while you are in the park?" questions the answers of the $68 \%, 73.3 \%, 62$ $\%$, and $76 \%$ of all participants were "Yes". However, there were no statistically significant difference between the manual wheelchair, wheelchair with battery, crutch and no device groups ( $p>0.05)$ (Table 2, 3 and 4).

Table 3. Structural adequacy of the city parks

\begin{tabular}{|c|c|c|c|c|c|c|c|c|c|c|c|c|c|}
\hline & & $\begin{array}{r}\text { Ma } \\
\text { Whee }\end{array}$ & hal & $\begin{array}{r}\text { Whe } \\
\text { Ba }\end{array}$ & $\begin{array}{l}\text { Ichair } \\
\text { th } \\
\text { tery }\end{array}$ & $\mathrm{Crt}$ & utch & No I & evice & & tal & & \\
\hline & & n & $\%$ & $\mathbf{n}$ & $\%$ & $\mathbf{n}$ & $\%$ & $\mathbf{n}$ & $\%$ & $\mathbf{n}$ & $\%$ & $\chi^{2}$ & $\mathbf{p}$ \\
\hline $\begin{array}{l}\text { Does the city park sufficiently } \\
\text { designed and suitable for your } \\
\text { disability? }\end{array}$ & $\begin{array}{l}\text { Yes } \\
\text { No }\end{array}$ & 0 & 0 & 0 & 0 & 0 & 0 & 0 & 0 & 0 & 0 & - & - \\
\hline $\begin{array}{l}\text { Does the city park's ground make } \\
\text { your movement harder? }\end{array}$ & No & 12 & 27.3 & 13 & $\begin{array}{l}74.5 \\
25.5\end{array}$ & 17 & $\begin{array}{l}62.2 \\
37.8\end{array}$ & 4 & $\begin{array}{l}40 \\
60\end{array}$ & $\begin{array}{l}102 \\
48\end{array}$ & $\begin{array}{l}68 \\
32\end{array}$ & 5.738 & 0.125 \\
\hline $\begin{array}{l}\text { Does the city park have any rest } \\
\text { areas that you can easily reach when } \\
\text { you get tired? }\end{array}$ & $\begin{array}{l}\text { Yes } \\
\text { No }\end{array}$ & 26 & $\begin{array}{l}59.1 \\
40.9\end{array}$ & 20 & $\begin{array}{l}39.2 \\
60.8\end{array}$ & 33 & $\begin{array}{l}73.3 \\
26.7\end{array}$ & 6 & 60 & 85 & $\begin{array}{l}56.7 \\
43.3\end{array}$ & 11.566 & $0.009 *$ \\
\hline $\begin{array}{l}\text { Do the locations of the trees restrict } \\
\text { your movement? }\end{array}$ & No & 26 & $\begin{array}{l}59.1 \\
40.9\end{array}$ & 25 & 51 & 16 & $\begin{array}{l}35.6 \\
64.4\end{array}$ & 1 & 90 & $\begin{array}{l}68 \\
82\end{array}$ & $\begin{array}{l}45.3 \\
54.7\end{array}$ & 10.414 & $0.015^{*}$ \\
\hline $\begin{array}{l}\text { Do the park lights enough for you to } \\
\text { move comfortably and safely at } \\
\text { night? }\end{array}$ & No & 18 & 40.9 & 22 & 43.1 & 22 & 48.9 & 6 & 60 & 68 & 45.3 & 1.544 & 0.672 \\
\hline $\begin{array}{l}\text { Does the city park have sufficient } \\
\text { area for your activities? }\end{array}$ & Yes & 43 & 2.3 & 48 & 94.1 & 43 & 95.6 & 1 & 10 & $\begin{array}{c}7 \\
143\end{array}$ & $\begin{array}{r}4.7 \\
95.3\end{array}$ & 1.381 & 0.710 \\
\hline
\end{tabular}

The answer of $56.7 \%$ of all participants were 'Yes' to the "Does the park have any rest areas that you can easily reach when you get tired?" question. Especially, the most of the wheelchair users with battery $(60.8 \%)$ stated that they could not find $(\mathrm{p}<0.05)$. The individuals with disability who stated that the locations of the trees in the parks were limiting their movement, were especially the wheelchair users $(59.1 \%)$ and wheelchair users with battery $(49 \%)(\mathrm{p}<0.05$, Table 3$)$. 
Table 4. Meeting the basic requirements and activities

\begin{tabular}{|c|c|c|c|c|c|c|c|c|c|c|c|c|c|}
\hline & & \multicolumn{2}{|c|}{$\begin{array}{c}\text { Manual } \\
\text { Wheelchair }\end{array}$} & \multicolumn{2}{|c|}{$\begin{array}{l}\text { Wheelchair } \\
\text { with } \\
\text { Battery }\end{array}$} & \multicolumn{2}{|c|}{ Crutch } & \multicolumn{2}{|c|}{$\begin{array}{c}\text { No } \\
\text { Device }\end{array}$} & \multicolumn{2}{|c|}{ Total } & \multirow[b]{2}{*}{$\chi^{2}$} & \multirow[b]{2}{*}{$\mathbf{p}$} \\
\hline & & $\mathbf{n}$ & $\%$ & $\mathbf{n}$ & $\%$ & $\mathbf{n}$ & $\%$ & $\mathbf{n}$ & $\%$ & $\mathbf{n}$ & $\%$ & & \\
\hline Could you access to the drinking-water & Yes & 27 & 61.4 & 35 & 68.6 & 24 & 53.3 & 7 & 70 & 93 & 62 & & \\
\hline area in the city park? & No & 17 & 28.6 & 16 & 31.4 & 21 & 46.7 & 3 & 30 & 57 & 38 & 2.665 & 0.446 \\
\hline $\begin{array}{l}\text { Could you access to rest-rooms in the } \\
\text { city park? }\end{array}$ & $\begin{array}{l}\text { Yes } \\
\text { No }\end{array}$ & $\begin{array}{l}3 \\
41\end{array}$ & 93.2 & 41 & 80.4 & 38 & $\begin{array}{l}15.6 \\
84.4\end{array}$ & 9 & 90 & $\begin{array}{l}21 \\
129\end{array}$ & $\begin{array}{l}14 \\
86\end{array}$ & 3.440 & 0.329 \\
\hline $\begin{array}{l}\text { Could you find everything in the city } \\
\text { park that you need (bench, drinking } \\
\text { water, waste basket etc.)? }\end{array}$ & Yes & 12 & 27.3 & 11 & 21.6 & 11 & 24.4 & 4 & 40 & 40 & 73.3 & 6.482 & $0.009 *$ \\
\hline $\begin{array}{l}\text { Could you use the city park for your } \\
\text { social activities (picnic etc.)? }\end{array}$ & No & 21 & 52.3 & 21 & 58.8 & 22 & 48.9 & 9 & 10 & 74 & $\begin{array}{l}49.3 \\
50.7\end{array}$ & 8.076 & 0.044 \\
\hline $\begin{array}{l}\text { Could you use the city park for your } \\
\text { sportive activities? }\end{array}$ & Yes & 40 & 90.9 & 47 & 92.2 & 45 & 100 & 1 & 10 & $\begin{array}{c}9 \\
141\end{array}$ & $\begin{array}{c}6 \\
94\end{array}$ & 4.209 & 0.240 \\
\hline $\begin{array}{l}\text { Could you benefit from cafes in the city } \\
\text { park? }\end{array}$ & Yes & 20 & 45.5 & 32 & 62.7 & 21 & 46.7 & 1 & 10 & 74 & $\begin{array}{r}49.3 \\
1\end{array}$ & 10.253 & $0.017^{*}$ \\
\hline
\end{tabular}

All the individuals with disability who participated in this study, stated that the park's design was not sufficient and suitable enough (100\%) (Table 3). When being able to benefit from cafes in the park is asked, it was recorded that more wheelchair users with battery $(62.7 \%)$ benefitted from them, than the other groups ( $p<$ 0.05 , Table 4). Meanwhile, half of the wheelchair users $(54.5 \%)$ and crutch users $(53.3 \%)$ stated that they cannot benefit (Table 4). The percentage of participants who stated as "No" to the "Could you use the park for your sportive activities?" question was $94 \%$, "Could you use the park for your social activities (picnic etc.)?" question was $50.7 \%$, "Does the park meet your toilet needs?" question was $86 \%$, "Can you use the car parking reserved for individuals with disability?" question was $83.3 \%$, "Do the park lights enough for you to move comfortably and safely at night?" question was $54.7 \%$, "Does the park have sufficient area for your activities?" question was $95.3 \%(p>0.05$, Table $3-4)$. In association with these results most of the participants $(81.3 \%)$ stated that they cannot spend time in the park efficiently and the difference was not significant between the groups (Table 2).

\section{Discussion and Conclusion}

City parks have an important place in terms of participation of individuals with disability to the social life and their physical functions. This study investigated the suitability and utilization of city parks for the individuals with disability and comparison was done by grouping all individuals according to the auxiliary devices that they used. This is a valuable study in terms of stating that all individual were part of the social society and this is the corner stone for the commonwealth. This study found that city parks were both unsuitable for disabled use and not accessible to disabled people. 
Ensuring physical fitness in urban parks is the most fundamental responsibility municipalities to be sure that people with disabilities are fully involved in social life and benefit from all possibilities of social life in equal conditions with other individuals (Güngör, Demir, and Polat 2016). Fortunately, country or city administrations are making efforts in this sense and, studies examining city parks are increasing in the literature. While the previous studies are single centered (Bromley, Matthews, and Thomas 2007; Nary, Froehlich, and White 2000; Sanmargaraja and Wee 2015), our study is multi-centered (Hatay, Şanliurfa and Gaziantep cities). In consequence, this design makes the results of this study valuable. The conception of the individuals with disability was questioned from three perspectives. These were accessibility and usage of city parks, structural adequacy of city parks, and basic needs and social activity areas in city parks.

Research on the wheelchair users in the urban context is limited. Although there is extensive geographical and other research relating to planning and changing the city center, rarely does the literature make other than passing reference to the needs of disabled people (Bromley, Matthews, and Thomas 2007). People with disabilities face many challenges in parking cars in urban parks, including limited availability of reserved areas for their use and unauthorized individuals uses these reserved areas. In a study that done by Bromley et al. on city transportation of disabled individual using wheelchairs, $56 \%$ of the participants found car parks usable and high quality (Bromley, Matthews, and Thomas 2007). In this study, it was determined that $83.3 \%$ of disabled individual could not use parking lot in city parks reserved for the individuals with disability. All of the disabled individuals who do not use a device stated that they could not use, while just $11.4 \%$ wheelchair users stated that they could use it (Table 3). There was no difference between the groups regarding car park usage $(\mathrm{p}>0.05)$ (Table 3). Especially disabled individual who use wheelchairs are the most affected by the problems encountered during access / transportation. However, all individuals with a physical disability are directly affected by all these problems whether they use or not an auxiliary vehicle (Nary, Froehlich, and White 2000; Rimmer et al. 2017). So, these results underline the importance of design of and improvements in city parks should be done to satisfy all the needs of all individuals in the community. Regarding accessibility in cities, the national accessibility monitoring system is mentioned in the 4th article / 1 of the Accessibility Monitoring and Inspection Regulation (Uçar and Şemşit, 2019: 19). According to this system, it is necessary to follow the implementation of accessibility standards in all kinds of structures such as existing official buildings, all existing roads, sidewalks, pedestrian crossings, open and green areas, social and cultural building areas, etc. However, the results of our study show that urban parks are not adequately inspected or regulated. As a result, the urban parks we researched were not suitable for the use of disabled people.

While $12.7 \%$ of individual with disabilities are hesitant to use city parks in suitable weather conditions, 94.7 $\%$ of them hesitated to use city parks in unfavorable weather conditions. Also, there was a significant difference between the groups for both weather conditions ( $p<0.05$, Table 2 ). Especially, more individuals in no assistive device group stated that they hesitate to use city parks both in favorable weather conditions and bad weather conditions, than the other groups. The relationship between the physical environment and the weakness of movement in disabled individuals was an evidence for the significant effect of weather (the temperature of the air, the floor is wet or icy and precipitation type) on the movement (Shumway-Cook et al. 2003). Disabled individuals who use this assistive device for mobility can create numerous difficulties in navigating the environment, especially in rainy, stormy and snowy weather (Wee 2008). Indeed, poor weather maintenance, for example, can create difficulties when snow and water accumulation make ramps inaccessible for individuals with disabilities (Lemaire et al. 2010; Ståhl et al. 2008). In this study, it was determined that the use of city parks in unfavorable weather conditions dropped, may be because of experiencing more the difficulties, which could also include the increment in the feelings of fear of sliding and falling (Lemaire et al. 2010; Skinner, Yantzi, and Rosenberg 2009). Because $73.3 \%$ of the all participants stated that they are afraid of falling and almost half of them stated that they had experienced an accident during their walks in the city parks. Additionally, this situation and reduced availability of the park could restrain them from using their existing potentials and reduce their independence. In relation with these, just 13.6 of wheelchair, 27.5 of the wheelchair with battery, $17.8 \%$ of the crutch, none of the no device user group and totally $18.7 \%$ of all participants declared that they could spend time in the park efficiently (Table 2). With this result about the usage of city parks led us to conclude how valuable it is to evaluate city parks according to geographical weather conditions and from the perspective of individuals with disability, too. 
Large number of people with disability have transportation problems and were thus far from being social individuals (Sanmargaraja and Wee 2015). Butler et al point out that the most common problems, regardless of the type of space used by disabled individuals, is that the design and organization of spaces are not appropriate (Butler and Bowlby 1997). Almost similar with the literature, in this study, all of the participants stated that the city parks design were not sufficiently suitable for usage of individuals with disabilities. In this context, when we asked the participants about the structure of the city parks, it was stated that the ground (68 $\%$ ) and lighting (54.7\%) of the park were faulty or incomplete, especially by more individuals in the wheelchair without and with battery user groups $(\mathrm{p}>0.05)$ (Table 3$)$. Similar to the results of this study; Perry et al. stated that none of the 21 parks had adequate lighting in their study (Perry et al. 2018). The safety and availability of parks for the disabled reduces at night, and social and physical activities are restricted accordingly (Van Hecke et al. 2016). In order to benefit from the city parks for all periods of time in a day, and to increase the social participation of the individuals with disabilities, eliminating the deficiencies which were related with lighting, ground, entrance, and parking areas should be considered during design of the city parks. Absence of appropriate design increases the dependence. It was recorded that the humanitarian needs of the most of the participants in all groups increased during their city park visits, due to these mentioned inadequacies that the participants suffered. The inability of disabled groups to access or use the environment, or the incidence of environments that impede or disadvantage particular groupings is a concern for disabled people (Imrie and Thomas 2008). Also, according to the Republic of Turkey Ministry of Family, Labor and Social Services, Accessibility Monitoring and Supervision Regulation dated 20 July 2013 and numbered 28713. "Accessibility: It refers to the safe and independent access and use of buildings, open spaces, transportation and information services, and information and communication technology by persons with disabilities". Although it seems that the accessibility and usability of city parks are preserved with the regulation, most of our participants stated that urban parks are not suitable (Uçar and Şemşit, 2019: 18).

Kitchin and Law stated that existing toilets were poorly designed and that this lack severely limits the daily physical behavior of disabled individual (Kitchin and Law 2001). So much so that, Perry et al. reported that only 6 of the 21 parks have a toilet, in addition to this accessibility to toilets was limited and the design was not appropriate (Perry et al. 2018). Similarly, $86 \%$ of disabled individual in this study said they could not access to rest-rooms and meet their toilet needs in city parks, especially the individuals in the wheelchair users group (93.2\%) ( $p>0.05$, Table 4). Nevertheless, it is an unacceptable situation to suffer from obstacles faced for the need of toilet due to existing health problems. However, we claim that disabled toilets are at the heart of contemporary life struggles. Disabled toilets should be shaped together with the concepts of citizenship and social justice. Indeed, ergonomic design of toilets is highly illustrative of the sociospatial processes that regulate and exclude disabled people from everyday spatial arenas, and reveals the extent to which many public spaces represent 'landscapes of exclusion' (Kitchin and Law 2001).

Half of the individuals with disabilities stated that they did not benefit from the cafes in the park, especially individuals in who did not use auxiliary device group were more than the others $(90 \%, \mathrm{p}<0.05)($ Table 4$)$. There were limited number of studies that questioned the use of cafe in the city parks of the disabled in the literature. One of the studies that was on students with disabilities was stated that the students had psychological problems due to the restricted access to the cafeteria (Graham et al. 2014). Furthermore, cafeterias are important for disabled individuals to communicate socially with other individuals (Bates and Davis 2004). For this reason, cafeterias significantly contribute to the success of disabled people to become social individuals. The fact that the cafes are the factors that enable city parks to be used in social life, it seems that the city parks that was inspected in this study cannot fulfill this function.

Most (94\%) of the disabled individuals stated that they could not use the city parks for sportive purposes. Although there is no significant difference between the groups ( $\mathrm{p}>0.05$ ), the 'No' response of the groups varies between $90-100 \%$ (Table 4). While 'persons with disabilities' is a large heterogenous group, physical activity is particularly important because this population has a higher risk of physical inactivity and associated longterm health conditions compared to those without disability (Krahn, Walker, and Correa-De-Araujo 2015; Rimmer and Marques 2012). For this reason that providing an environment to exercising is important for the physical and mental health of a disabled individual (Barnes and Mercer 2005). We found that it is almost impossible to exercise and do sports in city parks in this study. The recently published Global Action Plan on 
Physical Activity1 specifically states the need of "create supportive spaces and places that promote and safeguard the rights of all people, of all ages and abilities, to have equitable access to safe places and spaces in their cities and communities in which they can engage in regular physical activity." (Lawson 2018). Despite these good intentions, we have an opinion that none of the parks in this study met the criteria included in guidelines for accessible park and playground design (Perry et al. 2018). The deficiencies or absences in city parks' access and usage, structural adequacy, and meeting the basic requirements and activities premised to obtain this conclusion.

The evaluation method of this study included questionnaires, which was subjective data. The limitation of this study was the lack of an objective questionnaire. In future studies, besides the subjective questionnaires asked to the disabled people, an objective questionnaire or scale that examines the park's structure could be included. On the other hand, possible differences could also be questioned in terms of grouping the individuals according to gender, age, and socio-economic status in the future studies. In addition, a more comprehensive assessment of the urban parks could be done by a valid and reliable assessment tool, in addition to the questionnaires asked to the individuals with disability, in the future studies.

In the literature, studies on city parks have been carried out according to diseases or a single type of auxiliary device. In this respect, our study offers significant results in terms of evaluating parks by the individuals with different type of disability type, disability level and auxiliary device user. The basic needs and arrangements were focused in this study. It is also assumed that the arrangements, which could be done by only removing the obstacles from the physical framework, are the most necessary adaptations to achieve the full participation of the disabled person in the social life and to benefit from all possibilities of social life on equal conditions as other individual. From these points it is believed that this study pointed out important results that could be considered by local and central government, in addition to literature focusing on the individuals with disability. Municipalities should give more importance to the usage of city parks from the perspective of individuals with disabilities, while organizing city parks. The need for harmonization with EU policies and practices, both the Law No. 5378 and the Accessibility Regulation oblige both central government and local government officials to ensure and increase accessibility in cities equally. City administrations need to be sensitive about the participation of disabled people in social life and it is the most important duty to provide them with this right fully and equally. However, neglecting and not performing such an important duty means a violation of human rights.

Parks are places where all people and especially disabled people socialize. Therefore, the suitable design of the parks for disabled people is extremely important. The structure of the parks should be analyzed from the perspective of the individuals with disability. Meanwhile, the city parks must meet all individual's own basic and social needs and activities.

Acknowledgements: We would like to thank all participants and physiotherapists Sahir HABIP, Erdinc YILDIRIM, Emine SEKER, Saniye AYTEKIN, Dilek ATICI for their cooperation to collect the data.

Declaration of interest statement: The authors have no conflicts of interest to declare. This research did not receive any specific grant from funding agencies in the public, commercial, or not-for-profit sectors.

Funding: The author(s) received no financial support for the research, authorship, and/or publication of this article.

Associated Grant Projects: There is no associated grant project.

Compliance with Ethical Standards: All participants gave written informed consent before participation, and the study protocol conformed to the standards for human experiments set by the Declaration of Helsinki and was approved by the Local Ethics Committee (42598783-050-12-7855).

Author Contributions: E.D-H., N.C-K.: Conceptualization; E.D-H., N.C-K., F.B.: Data curation; E.D-H., N.C-K.: Formal analysis; N.C-K., F.B.: Investigation; N.C-K., F.B.: Methodology; N.C-K: Project administration; N.C-K., F.B., O.G.: Resources and Supervision; N.C-K., F.B., O.G.: Roles/Writing - original draft; N.C-K., F.B., O.G., E.D-H: Writing - review \& editing. 


\section{References}

Barbotte, E., Guillemin, F., \& Chau, N. (2001). Prevalence of impairments, disabilities, handicaps and quality of life in the general population: a review of recent literature. Bulletin of the World Health Organization, 79(11), 1047-55. PMID: 11731812.

Barnes, C., \& Mercer, G. (2005). Disability, work, and welfare: challenging the social exclusion of disabled people. Work, Employment and Society, 19(3), 527-545. doi: 10.1177/0950017005055669

Bates, P., \& Davis, F. A. (2004). Social capital, social inclusion and services for people with learning disabilities. Disability \& Society, 19(3), 195-207. doi: 10.1080/0968759042000204202

Bekci, B. (2012). The investigation of transportation axes with respect to accessibility for people having disabilities: the case of the Bartin city. Journal of Bartin Faculty of Forestry, 14(21), 26-36. https://dergipark.org.tr/tr/download/article-file/39973

Bromley, R. D., Matthews, D. L., \& Thomas, C. J. (2007). City centre accessibility for wheelchair users: The consumer perspective and the planning implications. Cities, 24(3), 229-241. doi: 10.1016/j.cities.2007.01.009

Bulgan, G., \& Göktaş, P. (2016). Comparison of X, Y And Z Generation About Accessibility of Disabled Tourism (Turkish). Journal of Economics and Management Research, 5:24-49. https://dergipark.org.tr/en/download/article-file/1355153

Butler, R., \& Bowlby, S. (1997). Bodies and spaces: an exploration of disabled people's experiences of public space. Environment and Planning D: Society and Space, 15(4), 411-433. doi: 10.1068/d150411

Eşkil, Ö. Y. (2011). Study of Ankara urban banks in the context of outdoor design features for the disabled (Turkish). M.Sc. Thesis, Bartın University Institute of Science; 2011. https://acikerisim.bartin.edu.tr/handle/11772/119?show=full

Graham, B. C., Keys, C. B., McMahon, S. D., \& Brubacher, M. R. (2014). Transportation challenges for urban students with disabilities: Parent perspectives. Journal of Prevention \& Intervention in the Community, 42 (1), 45-57. doi: 10.1080/10852352.2014.855058

Güngör, S., Demir, M., \& Polat, A. T. (2016). A Research on accessibilty of Urban Parks by disabled users. International Journal of Research in Social Sciences, 6(12), 578-94.

Harris, F., Yang, H. Y., \& Sanford, J. (2015). Physical environmental barriers to community mobility in older and younger wheelchair users. Topics in Geriatric Rehabilitation, 31(1), 42-51. doi: 10.1097/TGR.0000000000000043

Imrie, R., \& Thomas, H. (2008). The interrelationships between environment and disability. Local Environment, 13(6), 477-483. doi: 10.1080/13549830802259748

Kitchin, R., \& Law, R. (2001). The socio-spatial construction of (in) accessible public toilets. Urban Studies, 38(2), 287-298. doi: 10.1080/00420980124395.

Krahn, G. L., Walker, D. K., \& Correa-De-Araujo, R. (2015). Persons with disabilities as an unrecognized health disparity population. American Journal of Public Health, 105(S2), S198-S206. doi: 10.2105/AJPH.2014.302182.

Lawson, H. A. (Ed.). (2018). Redesigning physical education: An equity agenda in which every child matters. Routledge. ISBN: 9780367896218

Lemaire, E. D., O'Neill, P. A., Desrosiers, M. M., \& Robertson, D. G. (2010). Wheelchair ramp navigation in snow and ice-grit conditions. Archives of Physical Medicine and Rehabilitation, 91(10), 1516-1523. doi: 10.1016/j.apmr.2010.07.215

Nary, D., Froehlich, A. K., \& White, G. (2000). Accessibility of fitness facilities for persons with physical disabilities using wheelchairs. Topics in Spinal Cord Injury Rehabilitation, 6(1), 87-98. doi: 10.1310/B9FH-7X8B-HUBR-3RHN

Özdingiş, N. (2007). A Research on The Evaluation of Accessibility of The Urban Parks in Istanbul By The Physically Handicapped People (Turkish). Master of Science, Institute of Science. University of Bahçeşehir.

http://acikerisim.bahcesehir.edu.tr:8080/xmlui/bitstream/handle/123456789/1007/071510.pdf?sequence= $1 \&$ isAllowed $=\mathrm{y}$

Perry, M. A., Devan, H., Fitzgerald, H., Han, K., Liu, L. T., \& Rouse, J. (2018). Accessibility and usability of parks and playgrounds. Disability and Health Journal, 11(2), 221-229. doi: 10.1016/j.dhjo.2017.08.011.

Rimmer, J. H., \& Marques, A. C. (2012). Physical activity for people with disabilities. The Lancet, 380(9838), 193-195. doi: 10.1016/S0140-6736(12)61028-9 
Rimmer, J. H., Padalabalanarayanan, S., Malone, L. A., \& Mehta, T. (2017). Fitness facilities still lack accessibility for people with disabilities. Disability and Health Journal, 10(2), 214-221.doi: 10.1016/j.dhjo.2016.12.011

Sanmargaraja, S., \& Wee, S. T. (2015). Challenges faced by the disabled people while travelling in the Malaysian National Parks. Facilities, 3(4), 46-51.

Shumway-Cook, A., Patla, A., Stewart, A., Ferrucci, L., Ciol, M. A., \& Guralnik, J. M. (2003). Environmental components of mobility disability in community-living older persons. Journal of the American Geriatrics Society, 51(3), 393-398. doi: 0.1046/j.1532-5415.2003.51114.x

Skinner, M. W., Yantzi, N. M., \& Rosenberg, M. W. (2009). Neither rain nor hail nor sleet nor snow: Provider perspectives on the challenges of weather for home and community care. Social Science \& Medicine, 68(4), 682-688.doi: 10.1016/j.socscimed.2008.11.022

Smith, E. M., Sakakibara, B. M., \& Miller, W. C. (2016). A review of factors influencing participation in social and community activities for wheelchair users. Disability and Rehabilitation: Assistive Technology, 11(5), 361-374. doi: 10.3109/17483107.2014.989420

Ståhl, A., Carlsson, G., Hovbrandt, P., \& Iwarsson, S. (2008). "Let's go for a walk!": identification and prioritisation of accessibility and safety measures involving elderly people in a residential area. European Journal of Ageing, 5(3), 265-273. doi: 10.1007/s10433-008-0091-7

Uçar, A., \& Şemşit, S. (2019). Disability Employment in Accessible City Implementations in the EU Accession Process: Case of Manisa Metropolitan Municipality. Ö. Yaşar, N. Önsal, D. B. Saripek (Ed.), Engellilerin İstihdami ve Sosyal Koruma (13-26. ss.). Ankara; Büyük Anadolu Medya Grup.

Uçar, A., Şemşit, S., \& Negiz, N. (2017). Smart City Implementations In The EU And Reflections In Turkey (Turkish). Suleyman Demirel University Journal of Faculty of Economics \& Administrative Sciences, 22, 1785-98. https://ibfdergi.sdu.edu.tr/assets/uploads/sites/352/files/yil-2017-cilt-22-sayi-kayfor15-yazi1930122017.pdf

Van Hecke, L., Deforche, B., Van Dyck, D., De Bourdeaudhuij, I., Veitch, J., \& Van Cauwenberg, J. (2016). Social and physical environmental factors influencing adolescents' physical activity in urban public open spaces: A qualitative study using walk-along interviews. PloS One, 11(5), e0155686. doi: 10.1371/journal.pone.0155686

Wee, J. Y. M. (2008). Factors affecting activities and participation in persons with disabilities-informing models and measures. PhD Thesis. Queen's University Kingston, Ontario, Canada. 2008. https:/qspace.library.queensu.ca/bitstream/handle/1974/1242/Wee_Joy_YM_200710_MSC.pdf?sequenc $\mathrm{e}=1$ \&isAllowed $=\mathrm{y}$

Yılmaz, T., Gökçe, D., Șavklı, F., \& Çeşmecì, S. (2012). A study on young disabled people's use of common areas in the university campuses example of Olbia Culture Center in Akdeniz University. Journal of Tekirdag Agricultural Faculty, 9(3), 1-10. 
F.Ü. Sosyal Bilimler Dergisi 2021-31/3 